\title{
Lactic Dehydrogenases of Strains of the Genus Leuconostoc
}

\author{
By ELLEN I. GAR VIE \\ National Institute for Research in Dairying, University of Reading
}

(Accepted for publication 30 May 1969 )

\begin{abstract}
SUMMARY
The lactic dehydrogenases of II strains of the genus Leuconostoc were examined. All possessed a $\mathrm{D}(-)$ but no $\mathrm{L}(+)$ NAD-dependent lactic dehydrogenase, and three strains (I L. mesenteroides and 2 L. paramesenteroides) also had $\mathrm{D}(-)$ and $\mathrm{L}(+)$ NAD-independent lactic dehydrogenases. The NADdependent enzyme of the seven strains belonging to the species $L$. mesenteroides, $L$. dextranicum, $L$. paramesenteroides, $L$. lactis and $L$. cremoris moved together during electrophoresis in acrylamide gel. The enzymes of the other four strains, all $L$. oenos, were close together but widely separated from the enzyme of the other species. One strain of $L$. mesenteroides oxidized NADH without added pyruvate. The enzyme responsible was located after electrophoresis.
\end{abstract}

\section{INTRODUCTION}

Lactic acid bacteria have two types of enzyme for which lactate is substrate. The most active system catalyses the frequently reversible reaction pyruvate $\rightleftharpoons$ lactate and is NAD-dependent. This type of enzyme has been reported for a variety of species (Dennis \& Kaplan, 1960; van den Hamer, 1960). A second system, which is relatively less active and which is not NAD linked (independent), has also been found in several species (Snoswell, I963; van den Hamer, I960; Kaufmann \& Dikstein, 196I). The function of this second system is not yet clear; Snoswell (1963) reported the conversion lactate $\rightarrow$ pyruvate by the NAD-independent enzymes of a strain of Lactobacillus $(\mathrm{Lb})$ plantarum but was unable to reverse the reaction. Another type of enzyme forming lactic acid was found by van den Hamer ( 1960 ) in $\mathrm{Lb}$ casei. In this case methyl glyoxal and not pyruvate was the substrate and the product was $\mathrm{D}(-)$ lactic acid. In the genus Leuconostoc the species are ill defined and appear to merge one into the other. A study of the electrophoretic pattern of the lactic dehydrogenase of strains of this genus was made in an attempt to assist in their classification.

\section{METHODS}

Strains. These were selected from the National Collection of Dairy Organisms (NCDo) as typical of their species; they were grown in the media and under the conditions described by Garvie (1967a). The identity of the strains used is given in Fig. 3 .

\section{Preparation of cell extracts for electrophoresis}

Media. Two media were used, each prepared in two parts, A and B. Part A of Medium I consisted of $(\%, \mathrm{w} / \mathrm{v})$ : Bacteriological peptone (Oxoid), I $\cdot 0$; Bacto yeast extract (Difco), $0.5 ; \mathrm{KH}_{2} \mathrm{PO}_{4}, 0.5$; triammonium citrate, 0.5 ; sodium acetate, 0.25 ; $\mathrm{MgSO}_{4} \cdot 7 \mathrm{H}_{2} \mathrm{O}, 0.02 ; \mathrm{MnSO}_{4} \cdot 4 \mathrm{H}_{2} \mathrm{O}, 0.005$; Tween $80,0.1 \%(\mathrm{v} / \mathrm{v})$. Amounts to make 
I 1. of medium were dissolved in $900 \mathrm{ml}$. water adjusted to $\mathrm{pH} 6.5$ and autoclaved $12 \mathrm{I}^{\circ}$ for $\mathrm{I} 5 \mathrm{~min}$. Part B consisted of $100 \mathrm{ml}$. of $10.0 \%$ glucose in water, autoclaved at $12 \mathrm{I}^{\circ}$ for $\mathrm{I} 5 \mathrm{~min}$. The glucose solution was added to the rest of the medium before inoculation. Cysteine hydrochloride was added to $0.05 \%$ for Leuconostoc cremoris. The aqueous cysteine solution was sterilized by Seitz filtration.

Medium II was modified from medium I to grow strains of Leuconostoc oenos (Garvie, $1967 b$ ). In part A, $0.5 \%$ citric acid replaced ammonium citrate and the $\mathrm{pH}$ value was $4 \cdot 8$. Part B consisted of $10 \mathrm{~g}$. glucose; $0.5 \mathrm{~g}$. cysteine hydrochloride in $100 \mathrm{ml}$. tomato juice. This solution was sterilized by Seitz filtration.

A few non-acidophilic strains were also examined after growth in medium II. However, since these strains will not grow in media at $\mathrm{pH} 4 \cdot 8$, it was adjusted to $\mathrm{pH} 6 \cdot 5$.

Harvesting bacteria. Bacteria were harvested by centrifugation from cultures in the early stationary phase and washed in $0.85 \%(\mathrm{w} / \mathrm{v}) \mathrm{NaCl}$, suspended in about $10 \mathrm{ml}$. $0.85 \% \mathrm{NaCl}$ in $0.002 \mathrm{M}$-phosphate buffer $(\mathrm{pH} 7.0)$ and disrupted with a Soniprobe (Dawe, London) for $15 \mathrm{~min}$. at $20 \mathrm{kcyc}$. The tube containing the bacteria was kept in an ethanol bath at $-20^{\circ}$ during ultrasonic treatment. The suspensions were then centrifuged at $84,000 \mathrm{~g}$ for $20 \mathrm{~min}$. The supernatant fluid was tested at this stage for ability to oxidize NADH in the presence of pyruvate. It was then dialysed against $15.0 \%(\mathrm{w} / \mathrm{v})$ carbowax (20 M, Union-Carbide Co.) dissolved in a solution of $0.425 \%$ $(\mathrm{w} / \mathrm{v}) \mathrm{NaCl}$ in $0.002 \mathrm{M}$-phosphate buffer $\left(\mathrm{pH} 7^{\circ}\right.$ ). The volume was decreased to about $\mathrm{I} \cdot 0 \mathrm{ml}$. (for convenience in freeze-drying), divided into $0.1 \mathrm{ml}$. amounts, freeze-dried and the ampoules sealed under vacuum. They were stored at $4^{\circ}$. The lactic dehydrogenase in these preparations could still be detected easily after storage for 18 months to 2 years. When required the ampoule contents were taken up in distilled water to the required concentration.

\section{Testing for lactic dehydrogenase activity}

NAD-dependent enzymes. Three methods were used. (I) A screening test, which was used when determining the effect of various factors on the rate of enzyme action, consisted of adding $0.02 \mathrm{ml}$. enzyme preparation to $0.5 \mathrm{ml}$. of the solution used to locate the enzymes after electrophoresis by direct staining (see below). The time of development of the reduced nitro-blue tetrazolium was observed. (2) Oxidation of $\mathrm{NADH}$. The rate of oxidation of NADH was followed at $340 \mathrm{~nm} .: 0.02 \mathrm{ml}$. of enzyme preparation was added to $0.5 \mathrm{ml}$. of buffered substrate solution $(0.4 \mathrm{mg}$. NADH+ I $\mu$ mole sodium pyruvate in $3 \mathrm{ml}$. of $0.03 \mathrm{M}$-phosphate buffer $(\mathrm{pH} 7 \cdot 0)$ ). (3) Reduction of NAD. The reduction of NAD was followed at $340 \mathrm{~nm}$. when $0.02 \mathrm{ml}$. of enzyme preparation was added to $0.5 \mathrm{ml}$. of buffered substrate solution $(0.5 \mathrm{mg}$. NAD, roo $\mu$ mole sodium DL-lactate or $50 \mu$ mole $\mathrm{D}$ or L lactic acid (Ca or $\mathrm{Na}$ salt) in $\mathrm{I} \cdot 0 \mathrm{ml}$. of $\mathrm{o} \cdot \mathrm{I}$ M-tris $+\mathrm{Cl}$ buffer $(\mathrm{pH} 8 \cdot 3))$.

All these tests were done at room temperature (about $20^{\circ}$ ).

$N A D$-independent enzymes. The reduction of dichlorophenol indophenol was used to show the presence of the NAD-independent lactic dehydrogenase. The test solution consisted of $26 \mu \mathrm{g}$. dichlorophenol indophenol in $5.0 \mathrm{ml}$. of $0 . \mathrm{I}$ M-tris + maleate buffer ( $\mathrm{pH} \mathrm{6.3)}$ and lactate at the several concentrations given above; $0.02 \mathrm{ml}$. of enzyme preparation was added to $0.5 \mathrm{ml}$. of this solution and the reduction of the dichlorophenol indophenol followed at $600 \mathrm{~nm}$. 


\section{ELECTROPHORESIS}

The electrophoretic mobilities of enzymes were determined in acrylamide gel $\mathrm{I} \cdot 5 \mathrm{~mm}$. thick. The gel mixture consisted of I part tris + maleate buffer $(0.05 \mathrm{M})$ at $\mathrm{pH} 7 \cdot 0$ or $8.3,2$ parts acrylamide, $\mathrm{NN}^{\prime}$-methylene bis-acrylamide $(28.0 \mathrm{~g}$. acrylamide, $735 \mathrm{mg}$. bis-acrylamide in $100 \mathrm{ml}$. water) I part $0 \cdot 84 \%$ (v/v) N.N.N'. $N^{\prime}$. tetramethylethylenediamine and 4 parts $0.175 \%(\mathrm{w} / \mathrm{v})$ ammonium persulphate. The tank buffer consisted of $0.05 \mathrm{M}$-tris + maleate buffer at the same $\mathrm{pH}$ as the gel. Strips of $3 \mathrm{~mm}$. filter paper $\left(\mathrm{I} \times \mathrm{O}^{\cdot} \mathrm{I} \mathrm{cm}\right.$.) soaked in enzyme preparation to which a solution of bromphenol blue ( $1 \cdot 0 \mathrm{mg} . / \mathrm{ml}$.) had been added were inserted while wet into slits in the gel and a current of $200 \mathrm{~V}$. ( $13 \mathrm{~mA}$ ) applied for 3.5 to $4 \mathrm{hr}$, during which time the bromphenol blue migrated I I to $I 3 \mathrm{~cm}$. Electrophoresis was done in a room at $4^{\circ}$.

After electrophoresis at $\mathrm{pH} 8.3$ or $\mathrm{pH} 7.0$ the NAD-dependent enzymes were located by direct staining by immersing the gel in a solution consisting of $50.0 \mathrm{mg}$. NAD, $10.0 \mathrm{mg}$. nitro-blue tetrazolium, $2.0 \mathrm{mg}$. phenazine methosulphate, $10 \mathrm{~m}$-mole sodium DL-lactate (or $5.0 \mathrm{~m}$-mole $\mathrm{D}$ - or L-lactic acid ( $\mathrm{Ca}$ or $\mathrm{Na}$ salt)), in $100 \mathrm{ml}$. $0 \cdot \mathrm{I}$ M-tris $+\mathrm{Cl}$ buffer $\left(\mathrm{pH} \mathrm{8.3)}\right.$. The gels were left for $60 \mathrm{~min}$. at $22^{\circ}$ in the dark and then examined.

Alternatively a modification of the 'reverse' staining method of Tarmy \& Kaplan (I968) was used after electrophoresis at $\mathrm{pH} 77^{\circ}$. The gels were placed in a solution containing $100 \mathrm{mg}$. NADH, $2.5 \mathrm{~m}$-mole sodium pyruvate in $100 \mathrm{ml}$. $0.1 \mathrm{M}$-tris + maleate buffer $\left(\mathrm{pH} 77^{\circ}\right.$ ) for $30 \mathrm{~min}$. at $22^{\circ}$, washed twice in water and then stained in a solution containing $25.0 \mathrm{mg}$. nitro-blue tetrazolium $2.0 \mathrm{mg}$. phenazine methosulphate in $100 \mathrm{ml} .0 \cdot \mathrm{I} \mathrm{M}$-tris + maleate buffer $(\mathrm{pH} \mathrm{8.3)}$.

The NAD-independent enzymes were located after electrophoresis at $\mathrm{pH} 7 \cdot 0$ by using a solution containing $5 \cdot 2 \mathrm{mg}$. dichlorophenol indophenol in $100 \mathrm{ml}$. O. I M-tris + maleate buffer ( $\mathrm{pH} \mathrm{6.3)} \mathrm{and} \mathrm{lactate} \mathrm{as} \mathrm{above.} \mathrm{The} \mathrm{enzymes} \mathrm{showed} \mathrm{as} \mathrm{white} \mathrm{bands} \mathrm{on}$ a blue background. The distance of all the enzyme bands from the origin were calculated relative to a bromphenol blue migration of $10.0 \mathrm{~cm}$.

\section{Molecular weight of enzymes}

The approximate molecular weight (mol. wt) of the enzymes was determined by filtration through G 200, G I 50 and G roo Sephadex Superfine following the method of Andrews (1964). After swelling in $0 . \mathrm{I} \mathrm{M}-\mathrm{KCl}$ dissolved in $0.0 \mathrm{I} \mathrm{M}$-tris + maleate buffer $(\mathrm{pH} 7.5)$ thin layer $(0.5 \mathrm{~mm}$ ) $20 \times 20 \mathrm{~cm}$. glass plates were prepared. These were allowed to equilibrate for several hours in a flow of $0 . \mathrm{I} \mathrm{M}-\mathrm{KCl}$ in $0.0 \mathrm{I} \mathrm{M}$-tris + maleate buffer $(\mathrm{pH} 7 \cdot 5)$.

Samples $(0.02 \mu \mathrm{l}$.) of enzyme preparation were applied to the plates and developed with the buffer for about $8 \mathrm{hr}$ at room temperature. Blue dextran (mol. wt 2,000,000) was used to indicate the buffer front. A paper copy of the Sephadex was taken and dried in a current of cool air. The papers were sprayed with a solution consisting of $10.0 \mathrm{mg}$. NAD, $2.0 \mathrm{mg}$. nitro-blue tetrazolium, $0.8 \mathrm{ml}$. phenazine methosulphate $(0.5 \mathrm{mg} . / \mathrm{ml}$.), $4.0 \mathrm{ml}$. sodium DL-lactate $(0.25 \mathrm{M}), 5.0 \mathrm{ml}$. tris $+\mathrm{Cl}$ buffer $(\mathrm{pH} 8.3 ; 0.2 \mathrm{M})$, water to $10.0 \mathrm{ml}$. Rabbit muscle lactic dehydrogenase (Boehringer, Mannheim) was used as reference and also enzyme preparations from Lactobacillus plantarum and Leuconostoc mesenteroides. The colour developed very quickly and the dye tended to diffuse. It was necessary to dry the papers in a current of warm air to stop the spots spreading. 


\section{RESULTS}

\section{$N A D$-dependent enzymes}

While the NAD-dependent enzymes utilize either pyruvate or lactate as substrate, the reaction rate is faster with pyruvate and the concentrations of substrate coenzyme and enzyme required for adequate detection of enzyme activity in solution are less than those needed for the reverse reaction. The use of lactate, however, has the advantage of indicating the concentration of enzyme preparation to be used for electrophoresis when the enzymes are to be detected by the direct-staining method and also the relative activity of the preparation with $\mathrm{L}(+)$ and $\mathrm{D}(-)$ lactic acid. The use of pyruvate only indicates the overall activity of $L(+)$ and $D(-)$ lactic dehydrogenases and has the disadvantage that some preparations oxidize NADH without addition of substrate (Dolin, 1955; Kline \& Mahler, 1965). This was particularly the case with Leuconostoc mesenteroides NCDO 523 which actively oxidized NADH irrespective of whether the strain was grown in medium I or medium II. The oxidation of NADH was observed in phosphate and tris + maleate buffer and both before and after dialysis of the cell extracts (Table I). Because of this activity it was not possible to demonstrate a NADH-linked pyruvate reductase in NCDO 523. Preparations from other leuconostoc strains oxidized NADH very slowly or not at all in the absence of pyruvate, and NAD was not reduced by any strain unless lactate was present.

Table 1. Oxidation of NADH by two strains of Leuconostoc mesenteroides

$$
\text { (NCDO } 768,523)
$$

Extinction at $340 \mathrm{~nm}$.

\begin{tabular}{|c|c|c|c|c|}
\hline \multirow[b]{2}{*}{ Time (min.) } & \multicolumn{2}{|c|}{ With pyruvate } & \multicolumn{2}{|c|}{ Without pyruvate } \\
\hline & Medium I & & Medium I & $\begin{array}{c}\text { Medium I } \\
\text { (enzyme conc. } \times \text { Io }\end{array}$ \\
\hline \multicolumn{5}{|l|}{ NCDO 768} \\
\hline 0 & 0.862 & & 0.900 & 0.900 \\
\hline I & 0.050 & & 0.900 & 0.875 \\
\hline 2 & - & & - & 0.875 \\
\hline 3 & 一 & & 0.900 & - \\
\hline 4 & - & & - & - \\
\hline \multirow[t]{2}{*}{5} & - & & 0.900 & - \\
\hline & Medium I & $\begin{array}{c}\text { Medium II } \\
\text { (initial pH 6.5) }\end{array}$ & Medium I & $\underset{\text { (initial pH 6.5) }}{\text { Medium II }}$ \\
\hline NCDO 523 & & & & \\
\hline 0 & 0.690 & 0.690 & 0.680 & 0.680 \\
\hline I & 0.480 & 0.341 & 0.608 & 0.330 \\
\hline 2 & 0.330 & 0.162 & 0.382 & $0 \cdot 145$ \\
\hline 3 & 0.211 & 0.090 & 0.200 & 0.085 \\
\hline 4 & 0.144 & 0.068 & 0.223 & - \\
\hline 5 & 0.104 & 0.064 & 0.173 & - \\
\hline
\end{tabular}

As expected NAD-dependent $\mathrm{D}(-)$ lactic dehydrogenase was active in all strains but some reduction of NAD was also generally found when $\mathrm{L}(+)$-lactate was used as substrate (Fig. I). This activity was not due to impurity in the isomeric lactate used, as both the $\mathrm{D}(-)$ - and $\mathrm{L}(+)$-lactates used were examined for traces of the other isomer by the methods described by Garvie (1967c). 


\section{Effect of substrate on enzyme activity}

Enzyme preparation from NCDO 523 reduced NAD more rapidly with $\mathrm{Ca} D(-)$ lactate than with Na DL-lactate as substrate (Table 2); with other strains the difference between the two substrates was slight. The enzyme of NCDO 523 might be stimulated by $\mathrm{Ca}^{2+}$ or, on the other hand, $\mathrm{L}(+)$-lactate might be acting as an inhibitor of the $\mathrm{D}(-)$ lactic dehydrogenase. The time of reduction of nitro-blue tetrazolium was 3 and 15 min. at $\mathrm{pH} 8.3$ and $7 \cdot 5$ respectively when $\mathrm{Ca} \mathrm{D}(-)$-lactate was substrate but was increased to 7 and $23 \mathrm{~min}$. when the same molar concentration of $\mathrm{Na} \mathrm{D}(-)$ lactate was used.

To test for inhibition of the $\mathrm{D}(-)$ lactic dehydrogenase by $\mathrm{L}(+)$-lactate, an enzyme preparation from NCDO 523 was exposed to $\mathrm{L}(+)$-lactate and NAD for $5 \mathrm{~min}$. before $D(-)$-lactate was added. The results are shown in Fig. 2. No inhibition of enzyme activity by $\mathrm{L}(+)$-lactate occurred. The difference between the results with $\mathrm{Na}$ DL-lactate and $\mathrm{Ca} \mathrm{D}(-)$-lactate were therefore apparently due to the effect of $\mathrm{Ca}$ ion.

Table 2. Reduction of NAD by Leuconostoc mesenteroides NCDO 523 with different substrates

\begin{tabular}{|c|c|c|c|}
\hline \multirow[b]{2}{*}{$\begin{array}{l}\text { Time } \\
\text { (min.) }\end{array}$} & \multicolumn{3}{|c|}{ Extinction at $340 \mathrm{~nm}$. } \\
\hline & $\begin{array}{l}\text { O. I M-Na-DL- } \\
\text { lactate }\end{array}$ & $\begin{array}{c}0.05 \mathrm{M}-\mathrm{D}(-) \\
\text { lactic acid (Ca salt) }\end{array}$ & $\begin{array}{c}0.05 \mathrm{M}-\mathrm{L}(+) \\
\text { lactic acid (Ca salt) }\end{array}$ \\
\hline $\mathbf{I}$ & 0.133 & - & - \\
\hline 2 & 0.158 & 0.449 & 0.048 \\
\hline 3 & 0.158 & 0.498 & 0.056 \\
\hline 4 & - & 0.498 & 0.063 \\
\hline 5 & 一 & - & 0.065 \\
\hline
\end{tabular}

Effect of $\mathrm{pH}$ value on enzyme activity

Table 3 shows the time of reduction of nitro-blue tetrazolium in the presence of various substrates and at various $\mathrm{pH}$ values by the enzyme preparation from Leuconostoc mesenteroides NCDO 768. No reduction took place in the absence of NAD. The reaction with NAD was fastest at pH 8.3. It was found that dichlorophenol indophenol could be used in place of the nitro-blue tetrazolium + phenazine methosulphate system.

Electrophoresis. Only one area of lactic dehydrogenase activity was detected for any strain. However, on several occasions the area was seen as two merging adjacent bands. Strong reduction of nitro-blue tetrazolium was obtained with $\mathrm{Ca} \mathrm{D}(-)$-lactate or with $\mathrm{Na}$ DL-lactate; slight reduction was observed with $\mathrm{Ca} \mathrm{L}(+)$-lactate.

Figure 3 shows the relative positions of all the enzymes found. The enzyme of all the non-acidophilic leuconostocs moved together. Two areas of activity were found for the acidophilic Leuconostoc oenos; these were close together and migrated much more slowly than the enzyme of the non-acidophilic strains. The slowest moving enzyme belonged to the two strains NCDO I674 and I823 dependent for growth on a factor in tomato juice (Garvie \& Mabbitt, 1967), while the faster moving lactic dehydrogenase of $L$. oenos was found in the strains which did not require tomato juice. To test whether the difference in enzyme pattern between the acidophilic and non-acidophilic strains was due to growth in different media L. mesenteroides NCDO 523 was grown in medium II and cell extracts examined. The lactic dehydrogenase was 


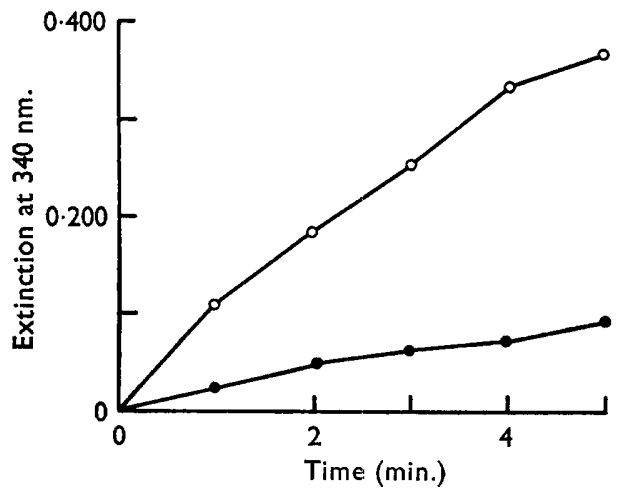

Fig. I

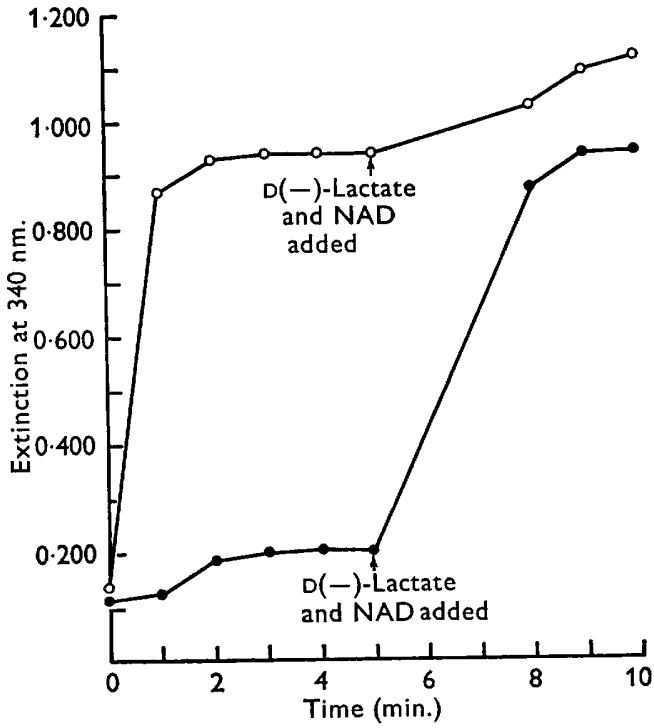

Fig. 2

Fig. I. Reduction of NAD at $\mathrm{pH} 8.3$ by enzyme preparations of Leuconostoc mesenteroides NCDO 768 with $\mathrm{D}(-)$ and $\mathrm{L}(+)$-lactate as substrate: $\mathrm{O}-\mathrm{O}$, calcium $\mathrm{D}(-)$-lactate as substrate; - calcium $\mathrm{L}(+)$-lactate as substrate.

Fig. 2. The effect of calcium $\mathrm{L}(+)$-lactate on the oxidation of calcium $\mathrm{D}(-)$-lactate by NAD-dependent lactic dehydrogenase at $\mathrm{pH} 8.3$ by enzyme preparations of Leuconostoc mesenteroides NCDO 523; $\bigcirc-O$, initial substrate calcium $\mathrm{D}(-)$-lactate; substrate calcium $\mathrm{L}(+)$-lactate.

Table 3. Time of reduction of nitro-blue tetrazolium and dichlorophenol indophenol by cell extracts of Leuconostoc mesenteroides NCDO 768 under various test conditions

Substrate

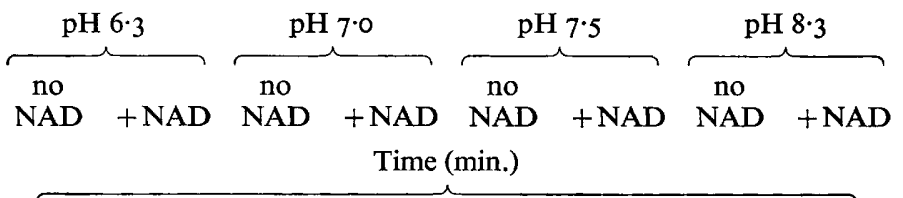

$\mathrm{H}^{+}$acceptor-DCPIP*
$\mathrm{Ca} \mathrm{D}(-)$-lactate
$\mathrm{Ca} L(+)$-lactate
$\mathrm{Na} \mathrm{D}(-)$-lactate
$\mathrm{Na} \mathrm{L}(+)$-lactate
Water
$\mathrm{H}^{+}$acceptor NBT + PMS $\$$
$\mathrm{Ca} \mathrm{D}(-)$-lactate
$\mathrm{Ca} \mathrm{L}(+)$-lactate
$\mathrm{Na} \mathrm{D}(-)$-lactate
$\mathrm{Na}(+)$-lactate
Water

$\begin{array}{rrrrrrrr}\text { I5 } & 6 & 28 & 7 & - & 5 & - & 6 \\ \text { I9 } & 36 & 90 & 40 & - & - & - & - \\ \text { I3 } & 6 & 60 & 6 & - & 8 & \text { nt } & \text { II } \\ 40 & 40 & - & - & - & - & \text { nt } & - \\ - & - & - & - & - & - & \text { nt } & - \\ - & 75 & - & 29 & - & 8 & - & 2 \\ - & - & - & - & - & 150 & - & 150 \\ - & 60 & - & 21 & - & 8 & - & 3 \\ - & - & - & - & - & 150 & - & 150 \\ - & - & - & - & - & - & - & -\end{array}$

* Dichlorophenol indophenol.

$\dagger$ NBT $=$ Nitro-blue tetrazolium.

$\ddagger$ Phenazine methosulphate.

nt $=$ not tested. 
identical with that present after growth in medium I. It was concluded that the differences between the acidophilic and non-acidophilic leuconostocs was not due to different growth conditions. The rate of migration of the enzymes was unaffected when the $\mathrm{pH}$ value of the electrophoresis buffer was decreased from $\mathrm{pH} 8 \cdot 3$ to $7 \cdot 0$.

Electrophoresis of NADH oxidase. After electrophoresis of enzyme preparations of Leuconostoc mesenteroides NCDO 523 two bands were found by using the 'reverse' staining technique when pyruvate $\mathrm{NADH}$ were in the reaction mixture. The faster
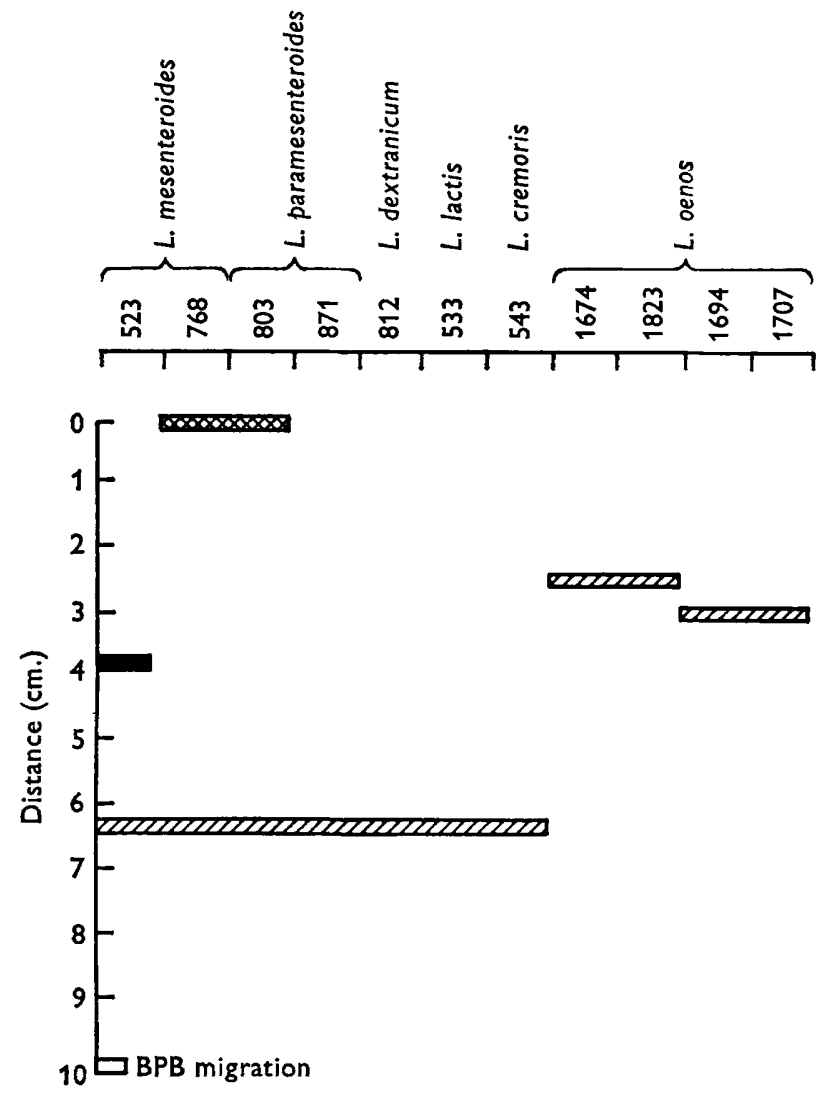

Fig. 3. The relative positions of lactic dehydrogenases and NADH oxidases of eleven strains of the genus Leuconostoc after electrophoresis in acrylamide gel; - NADH oxidase; 团, NAD-dependent $\mathrm{D}(-)$-lactic dehydrogenase;, NAD-independent lactic dehydrogenase-reacting with both $\mathrm{D}(-)$ - and $\mathrm{L}(+)$-lactate.

moving enzyme coincided with the $\mathrm{D}(-)$ lactic dehydrogenase. When pyruvate was absent this activity disappeared; however, the slower moving enzyme (NADH oxidase) was present and with undiminished intensity (Fig. 3). Other strains showed only one band i.e. the $\mathrm{D}(-)$ lactic dehydrogenase.

Molecular size of lactic dehydrogenase. Bacterial lactic dehydrogenases have been reported to be of different molecular weights. To see whether the different electrophoresis patterns were related to molecular size, crude extracts were examined by using thin-layer Sephadex plates. Several enzymes of known molecular weight were 
used as markers. Tarmy \& Kaplan (1968) gave a molecular weight of 80,000 for Leuconostoc mesenteroides lactic dehydrogenase, while Dennis, Reichlin \& Kaplan (I965) gave a molecular weight of 68,000 for the $\mathrm{D}(-)$ lactic dehydrogenase of Lactobacillus plantarum and $\mathrm{I} 55,000$ for the $\mathrm{L}(+)$ enzyme of the same species. Mammalian lactic dehydrogenase was estimated at I40,000 by Jaenicke \& Knof (I968).

Mammalian lactic dehydrogenase ran in advance of the $\mathrm{L}(+)$ enzyme of Lactobacillus plantarum (although the latter has the lower molecular weight) with the $\mathrm{D}(-)$ enzyme of the same strain hardly separated but behind the $\mathrm{L}(+)$ band. The $\mathrm{D}(-)$ lactic dehydrogenase of Leuconostoc mesenteroides and $L$. oenos was on a line with the $\mathrm{D}(-)$ enzyme of $L b$. plantarum. This would suggest that the $\mathrm{D}(-)$ enzyme all had a molecular weight of 70,000 to 80,000 .

\section{NAD-independent enzymes}

NAD-independent enzymes were not found in eight of the strains including Leuconostoc mesenteroides NCDO $523 ; L$. mesenteroides NCDO 768 and both strains of $L$. paramesenteroides (NCDO 803, NCDO 87I) had NAD-independent enzymes. Of these strains, NCDO 803 and NCDO 768 were more active than NCDO 87I. Table 3 shows the time of reduction of dichlorophenol indophenol by enzyme preparation of $L$. mesenteroides NCDO 768 under different conditions. These enzymes were most active at pH 6.3 and inactive at alkaline pH values. The phenazine methosulphate + nitro-blue tetrazolium system cannot act as hydrogen acceptor for the NAD-independent enzymes of this strain. All three strains reduced dichlorophenol indophenol with either $D(-)$ or $\mathrm{L}(+)$-lactate; the reaction was faster with the $\mathrm{D}(-)$ isomer in every strain.

Electrophoresis. The enzyme concentration in preparation from Leuconostoc paramesenteroides NCDO 87I was too low for any activity to be detected after electrophoresis. Both $L$. mesenteroides NCDO 768 and $L$. paramesenteroides NCDO 803 showed only one band, which did not move significantly from the point of origin, and which reacted strongly with $\mathrm{D}(-)$-lactate but only weakly with $\mathrm{L}(+)$-lactate. It is uncertain whether both NAD-independent enzymes were involved or whether the $\mathrm{D}(-)$ enzyme was reacting with both substrates, and the weaker $\mathrm{L}(+)$ enzyme was not located.

\section{DISCUSSION}

There is considerable variation in the electrophoretic mobilities of both $D(-)$ and $\mathrm{L}(+)$ lactic dehydrogenases between different species of the lactic acid bacteria (E. I. Garvie, unpublished). The fact that strains of five species in the genus Leuconostoc possessed enzymes which moved together is therefore exceptional. In view of the variations in other species the identical mobility in the case of the Leuconostoc species suggests that they possess a common lactic dehydrogenase, and further that the relationship between species is close, probably closer than between species of other lactic acid bacteria. This may explain why the differentiation of the non-acidophilic leuconostocs into species is not as clear cut as with other lactic acid bacteria.

While this study of the lactic dehydrogenases has not detected differences between the non-acidophilic species it has given further evidence that Leuconostoc oenos is a separate species. Peynaud (I968) suggested that the acidophilic leuconostocs should be divided into two species on the basis of pentose fermentation. Of the four strains examined here NCDO I674 (the type strain; Garvie, 1967 b) and NCDO I823 having the 
same lactic dehydrogenase, belong to the non-pentose fermenting group, while the two strains with the other lactic dehydrogenase both ferment arabinose. The lactic dehydrogenase pattern therefore gives support to the division of $L$. oenos suggested by Peynaud.

Genetically different isoenzymes of lactic dehydrogenase have not been recorded in bacteria. In other organisms where these isoenzymes occur they are usually widely separated on electrophoresis. Conformational isoenzymes (Markert, I968; Epstein \& Schechter, I968) on the other hand occur as adjacent bands and it is possible that the double band observed on some occasions with the leuconostoc enzyme preparations was of this nature.

When both $\mathrm{L}(+)$ - and $\mathrm{D}(-)$-lactates were used separately as substrates in the gel stain all NAD-dependent lactic dehydrogenase showed with both isomers. The reaction would be strong with one lactate but weak with the other. This was observed with rabbit muscle lactic dehydrogenase, as well as with the bacterial enzymes of a variety of strains of lactic acid bacteria. With those strains of bacteria having both $\mathrm{D}(-)$ and $\mathrm{L}(+)$ lactic dehydrogenase these observations could be explained by assuming that in every instance a trace of one enzyme was mixed in the bulk of the other; this would not be applicable to the enzymes of those bacteria having only one lactic dehydrogenase or with the mammalian lactic dehydrogenase. It appears therefore that lactic dehydrogenases are able to reduce some NAD in the presence of the unnatural isomer. In the case of the leuconostocs this was also apparent when testing for enzyme activity at $340 \mathrm{~nm}$. with $\mathrm{L}(+)$-lactate.

The function of the NAD-independent enzymes is unknown. The isomeric lactic acid formed by lactic acid bacteria from the fermentation of glucose during normal growth is no indication of the NAD-independent lactic dehydrogenase possessed by the bacteria. Pediococcus cerevisiae forming DL-lactic acid possess only an $\mathrm{L}(+)$ enzyme, while Lactobacillus casei forming only $\mathrm{L}(+)$ lactic acid has both a $\mathrm{D}(-)$ and $\mathrm{L}(+)$ NAD-independent enzyme (E. I. Garvie, unpublished). Similarly leuconostocs forming lactic $\mathrm{D}(-)$ acid also have both $\mathrm{L}(+)$ and $\mathrm{D}(-)$ NAD-independent lactic dehydrogenase.

\section{REFERENCES}

ANDREWS, P. (1964). Estimation of molecular weights of proteins by Sephadex Gel-filtration. Bio chem J. $91,222$.

DENNIS, D. \& KAPLAN, N. O. (1960). D- and L + lactic acid dehydrogenases in Lactobacillus plantarum. J. biol. Chem. 235,8 ro.

Dennis, D., Reichlin, M. \& Kaplan, N. O (1965). Lactic acid racenization. Ann. N.Y. Acad. Sci. II9, 868 .

Dolin, M. I. (1955). The DPNH oxidising enzymes of Streptococcus faecalis. II. The enzymes utilizing oxygen, cytochrome $C$, peroxide and 2-6 dichlorophenol indophenol or ferricyanide as oxidants. Archs. Biochem. Biophys. 55, 415.

EPSTEIN, C. J. \& SCHECHTER, A. N. (1968). An approach to the problem of conformational isoenzymes. Ann. N.Y. Acad. Sci. 151, 85.

GARVIE, E. I. (I967a). The growth factor and amino acid requirements of species of the genus Leuconostoc including Leuconostoc paramesenteroides sp.nov. and Leuconostoc oenos. J. gen. Microbiol. $48,439$.

GARVIE, E. I. (I967b). Leuconostoc oenos. sp.nov. J. gen. Microbiol. 48, 43I.

GARviE, E. I. $(1967 c)$. The production of $\mathrm{L}(+)$ and $\mathrm{D}(-)$ lactic acid in cultures of some lactic acid bacteria with a special study of Lactobacillus acidophilus NCDO 2. J. Dairy Res. 34, 3 I.

GarviE, E. I. \& MabBITt, L. A. (1967). Stimulation of the growth of Leuconostoc oenos by tomato juice. Arch. Mikrobiol. 55, 398. 
VAN Den Hamer, C. J. A. (1960). The carbohydrate metabolism of the lactic acid bacteria. Proefschrift of University of Utrecht.

JAENICKE, R. \& KNOF, S. (1968). Molecular weight and quaternary structure of lactic dehydrogenase. III. Comparative determination by sedimentation analysis, light scattering and osmosis. Eur.J. Biochem. 4, 157.

Kaufmann, E. \& Dikstern, S. (196I). A D-lactic dehydrogenase from Leuconostoc mesenteroides. Nature, Lond. 190, 346.

Kinne, E. S \& Mahler, H. R. (1965). The lactic dehydrogenases of E. coli. Ann. N.Y. Acad. Sci. II9, 905.

Markert, C. L. (1968). The molecular basis for isoenzymes. Ann. N.Y. Acad. Sci. 151, I4.

Peynaud, E. (1968). Etudes recentes sur les bactéries lactiques du vin. Fermentation et vinification. 2nd Symposium International d'oenologie, r, 219.

SNoswell, A. M. (1963). Oxidised nicotinamide-adenine-dinucleotide independent lactic dehydrogenases of Lactobacillus arabinosus 17/5. Biochim. biophys. Acta 77, 7.

TARMY, E. M. \& KAPLAN, N. O. (I968). Chemical characterization of D lactate dehydrogenase from Escherichia coli B. J. biol. Chem. 243, 2579. 